\title{
Article
}

\section{Job involvement, commitment, satisfaction and turnover: Evidence from hotel employees in Cyprus.}

Zopiatis, A, Constanti, P and Theocharous, A.L.

Available at http://clok.uclan.ac.uk/13142/

Zopiatis, A, Constanti, P and Theocharous, A.L. (2014) Job involvement, commitment, satisfaction and turnover: Evidence from hotel employees in Cyprus. Tourism Management, 41 . pp. 129-140. ISSN 0261-5177

It is advisable to refer to the publisher's version if you intend to cite from the work. http://dx.doi.org/10.1016/j.tourman.2013.09.013

For more information about UCLan's research in this area go to http://www.uclan.ac.uk/researchgroups/ and search for <name of research Group>.

For information about Research generally at UCLan please go to http://www.uclan.ac.uk/research/

All outputs in CLoK are protected by Intellectual Property Rights law, including Copyright law. Copyright, IPR and Moral Rights for the works on this site are retained by the individual authors and/or other copyright owners. Terms and conditions for use of this material are defined in the policies page.

\section{CLoK}

Central Lancashire online Knowledge www.clok.uclan.ac.uk

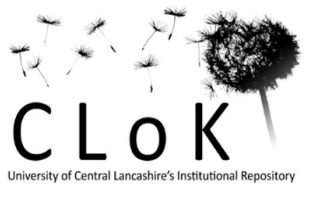




\title{
Job involvement, commitment, satisfaction and turnover: Evidence from hotel employees in Cyprus
}

\author{
Anastasios Zopiatis $^{\mathrm{a}, *}$, Panayiotis Constanti ${ }^{\mathrm{b}, 1}$, Antonis L. Theocharous ${ }^{\mathrm{a}, 2}$ \\ ${ }^{a}$ Department of Hotel and Tourism Management, Cyprus University of Technology, Spirou Araouzou 115, P.O. Box 50329, 3036 Limassol, Cyprus \\ ${ }^{\mathrm{b}}$ School of Business and Management, University of Central Lancashire (Cyprus), 12-14 University Avenue, Pyla, 7080 Larnaka, Cyprus
}

\section{H I G H L I G H T S}

- We investigate job satisfaction, involvement, organizational commitment and turnover intentions.

- Affective and normative organizational commitment, have positive associations with job satisfaction.

- Affective organizational commitment and satisfaction have negative associations with turnover.

- A negative association between intrinsic job satisfaction and turnover intention cannot be supported.

\section{A R T I C L E I N F O}

\section{Article history:}

Received 3 January 2013

Accepted 13 September 2013

\section{Keywords:}

Cyprus

Turnover intention

Job satisfaction

Job involvement

Organizational commitment

SEM

\begin{abstract}
A B S T R A C T
The study of attitudes at work seeks to enhance organizational knowledge and capabilities in developing an 'ideal' working environment that delivers exceptional customer service. The current study investigates the causal relationships of job involvement, organizational commitment (normative and affective), and job satisfaction (intrinsic and extrinsic), with the intention of hospitality employees in Cyprus to either remain at or leave their job. Utilizing structural equation modeling, positive associations were found between job involvement, affective and normative commitment, and intrinsic job satisfaction. Positive associations between affective and normative organizational commitment, and intrinsic and extrinsic job satisfaction were also found. In addition, negative associations between affective organizational commitment, extrinsic job satisfaction and turnover intention were revealed. However, a negative association between intrinsic job satisfaction and turnover intention was not supported. The implications of these results for future research are also discussed.
\end{abstract}

(c) 2013 Elsevier Ltd. All rights reserved.

\section{Introduction}

The tourism sector is highly labor intensive with the performance of its human resources being a significant and determining factor in its sustainability. Consequently, this reliance on human resources for its proper functioning and growth, demands both effective and efficient workforce practices in order for employees to perform at optimum levels, thereby enabling the sector to remain viable in a rapidly changing, and fiercely competitive, global environment (Ogbeide \& Harrington, 2011; Zopiatis \& Constanti, 2007). As organizations in the tourism sector have become increasingly aware that

\footnotetext{
* Corresponding author. Tel.: +357 25 002502; mobile: +357 99 482880; fax: +35725002653 .

E-mail addresses: anastasios.zopiatis@cut.ac.cy (A. Zopiatis), pconstanti@ uclan.ac.uk (P. Constanti), antonis.theocharous@cut.ac.cy (A.L. Theocharous).

1 Tel.: +357 24 694088/9; fax: +357 24812120 .

2 Tel.: +357 25002561 .
}

mismanagement of resources can lead to their demise, they have focused on cost minimization while simultaneously maintaining quality (Birdir, 2002; Hinkin \& Tracey, 2000). Thus informed, these organizations are encouraged by the literature (Gronroos, 2000; Karatepe \& Kilic, 2007; Zeithaml \& Bitner, 2000) to consider employee performance, as a means to gain competitive advantage.

Subsequently, scholars have investigated workplace issues that are likely to impact on employee attitudes in order to better understand, and therefore to develop strategies to improve both individual and organizational performance. One of the issues includes the tacit acceptance that turnover behavior is quite appropriate and an accepted element of life within the industry (Davidson, Timo, \& Wang, 2010; Iverson \& Deery, 1997). The profound impact that turnover behavior has on an organization's costs has increased the need for continual management vigilance in order to mitigate any likely adverse effects to the enterprise (Hinkin \& Tracey, 2000; Lashley, 2001; Ryan, Ghazali, \& Mohsin, 2011; Simons \& Hinkin, 2001). 
Others have posited that low levels of job satisfaction, which is impacted by routinization, role conflict and lack of promotional opportunity (Carbery, Garavan, O’Brien, \& McDonnell, 2003; Lambert, Lewig, \& Dollard, 2003), can have deleterious effects on the organization. In the same vein, two further universal dimensions of the work experience, organizational commitment and job involvement, can impact not only an employee's decision to quit an organization, but also on its bottom line results (Deery, Iverson, \& Walsh, 2002; Falkenburg \& Schyns, 2007; Johnson et al., 2005).

Upon scanning the job involvement, organizational commitment, job satisfaction, and turnover literature in Cyprus we found a barren landscape. Utilizing structural equation modeling (SEM) and grounding our research in the turnover, job satisfaction, job involvement and organizational commitment theories, we embarked on a theoretical and empirical journey to discover the relationships between the aforementioned workplace constructs. Before presenting an overview of the relevant literature which is synthesized with the development of several hypotheses, we provide the context and background of the study.

\section{Context and background}

Studies of the tourism industry's impacts on island destinations in the Mediterranean region have tended to focus on the sector's significant contribution to the destinations' economies. This includes a plethora of studies in other parts of the Mediterranean where island destinations have experienced periods of rapid growth, with its ensuing challenges (Garín-Munõz \& MonteroMartin, 2007; Knowles \& Curtis, 1999). Accompanying this rapid growth is a heavy dependence on tourism with its subsequent impacts (Palmer \& Riera, 2003), including seasonal demand which also impacts labor demand, the latter providing a myriad of challenges for those charged with managing an organization's human resources (Zopiatis \& Constanti, 2007). The study is therefore relevant and useful for at least two reasons.

Firstly, it may contribute to important practical implications at the micro-level. Cyprus, an island in the Eastern Mediterranean, joined the European Union in 2004 and the Euro-Zone in 2007. Its dependence on tourism is significant, accounting for $10 \%$ of its GDP in 2011 (Cyprus Tourism Organization, Annual Report 2011). In 2011, according to the Statistical Service of the Republic of Cyprus, 2.4 million tourists visited the island with tourism receipts reaching $€ 1.745$ billion Euros (Statistical Service of the Republic of Cyprus: Tourism Statistics, 1999-2011). The United Kingdom is the largest contributor, with $42.7 \%$ of tourism arrivals, followed by Russia (13.9\%), Germany (6.6\%) and Greece (5.8\%). Despite the current financial crisis caused by Cyprus' overexposure to Greek financial institutions, official statistics revealed an increase of $10.1 \%$ in tourist arrivals from the previous year. Impressive and noteworthy is the 49.2\% increase of tourist arrivals from Russia, a direct result of the country's extensive promotional campaign toward that particular market (Statistical Service of the Republic of Cyprus: Tourism Statistics, 1999-2011).

As a significant service industry, tourism's heavy reliance on human resources means that it must continually strive to remain competitive in a rapidly changing global environment (Sharpley \& Forster, 2003; Zopiatis \& Constanti, 2007). According to official figures the local tourism sector provided gainful employment in 2009 to 34,000 individuals (Statistical Service of the Republic of Cyprus: Labor Statistics, 2009). Unfortunately, the industry is impacted by the vagaries of seasonality; employment of a small number of permanent, core staff; with a reliance on peripheral labor, consisting mostly of migrant workers during periods of high demand. According to Zopiatis and Constanti (2007, p. 392) “...the effects of the country's European Union (EU) accession, and its close geographic proximity to some of the planet's conflict areas, give the Cyprus tourism industry a somewhat distinctive flavor" and challenges which accompany this distinction. Moreover, paradoxically and despite the growing numbers recorded in 2011 in both tourist arrivals and receipts, the industry continues its 'downsizing' tactics by terminating the employment of vast numbers of employees. This has culminated in local politicians calling for an independent inquiry into the industry's human resource practices (Psyllides, 2012).

Secondly, besides contributing to the body of knowledge at the micro-level, findings of the current study may present important practical implications at the macro-level. Garín-Munõz and Montero-Martin (2007) provide a lucid argument regarding the impacts of inbound tourism on island destinations. Clerides and Pashourtidou (2007) critique the need for Cyprus to rethink its tourism strategies if it is to become a key player in the international arena. An almost exclusive dependence on seasonal tourism creates fluctuating demands on infrastructures, making the destinations more susceptible to environmental degradation, and to global, as well as, regional trends. Subsequently, Cyprus' dependence on tourism for its development and economic well-being requires herculean efforts in order to maintain a delicate balance between development and degradation of the tourism product. Aligned with this, is the need for effective and efficient utilization, and management of the industry's human resources (Karatepe \& Kilic, 2007; Lanquar, 2011).

Successful enterprises in the luxury end of the market tend to place greater emphasis on the development and management of people (Baum, 2007). However, on a global scale, human resource management practices have a tendency to be characterized as ambiguous and inflexible (Conlin \& Baum, 2003), often unplanned and unstructured, lacking a cohesive strategy. This approach, labeled 'adhocism' (Baum, 2012, p. 125), has profound repercussions for island destinations with regard to recruitment, retention, training and career progression (Adler \& Adler, 2004; Baum, Hearns, \& Devine, 2007; Baum \& Lundtorp, 2000; Shakeela \& Cooper, 2009).

Having identified and defined the context, the relevant literature on which the study has been grounded is outlined in the next section while simultaneously formulating the research hypotheses.

\section{Literature review and hypotheses development}

The focus of the paper is on specific human resource practices which are likely to impact productivity and, by default, sustain profitability of organizations in the hospitality and tourism sector. Specifically, there now follows a review of the job involvement, organizational commitment, job satisfaction, and turnover intention literature, accompanied by the relevant hypothesis development.

\subsection{Job involvement and organizational commitment}

The seminal investigation by Allport (1943) conceptualized job involvement as active participation in one's job, or the degree to which employees are actively engaged in it, in order to fulfill their intrinsic needs. Fulfillment of these needs enables the achievement of personal satisfaction. In a later but significant contribution, Blau (1985) posited the view that job involvement provides the opportunity for individuals to make decisions, the foundation for strengthening their job involvement. Continuing his critique, Blau, citing Dubin's (1956) not insignificant contribution, informs us that job involvement is the perception that the work we do is so important that anything related to it or affected by it has a profound impact on our self-image. In a similar vein Paullay, Alliger, and 
Stone-Romero (1994) suggest that an integral part of employees' self-definition is the degree to which they are involved in their job. Consequently, highly-job-involved employees are more committed to their organization, invest substantial effort in order to achieve organizational objectives (Ineson, Benke, \& Laszlo, 2013; Rotenberry \& Moberg, 2007), and are thus less likely to turnover (Kanungo, 1979; Kuruüzüm, Cetin, \& Irmak, 2009; Pfeffer, 1994). Utilizing these constructs, and by synthesizing critically the work of Greenhaus (1971), Gordon, Philpot, Burt, Thompson, and Spiller (1980), and Morrow (1983), Blau (1985) makes a case for the relationship between these aspects of job involvement and organizational commitment.

Reflecting on Meyer and Allen's (1991) three dimensions of organizational commitment, Robbins and Judge (2007, p. 81) proceeded to define each dimension beginning with affective commitment as "the degree to which an employee identifies with a particular organization and its goals and wishes to maintain membership in the organization," i.e. employees remain at their current workplace because they want to. Continuance commitment was defined as "the perceived economic value of remaining with an organization compared to leaving it," i.e. they remain because they need to, while normative commitment can be described as "an obligation to remain with the organization for moral or ethical reasons," i.e. employees feel as though they should remain in the organization because they 'owe it' to their current employer.

Mathieu and Zajac (1990), Cohen (2000), and Ketchand and Strawser (2001), had their work deconstructed by Kuruüzüm et al. (2009) who posited the view that job involvement has a stronger relationship with both affective and normative commitment, than it has with continuance commitment. Based on the theoretical foundations laid by earlier work investigating these relationships (Allen \& Meyer, 1990; Hackett, Bycio, \& Hausdorf, 1994; Hartmann \& Bambacas, 2000; Tayyeb \& Riaz, 2004), which found the stronger relationships between job involvement and affective and normative commitment, we developed the following hypotheses:

$\mathrm{H}_{1}$ : There is a positive association between Job Involvement and Affective Organizational Commitment.

$\mathrm{H}_{2}$ : There is a positive association between Job Involvement and Normative Organizational Commitment.

\subsection{Job involvement and job satisfaction}

Having postulated the above hypotheses, the study also aimed to examine the association between the intrinsic and extrinsic aspects of job satisfaction and job involvement. Factors considered extrinsic include wages, supervision, and working conditions, implying that the satisfaction is derived from external stimuli, while the intrinsic factors include elements such as, the work itself and growth and recognition, providing satisfaction from one's efforts and personal achievement. Whether employees achieve any job satisfaction depends on how good they feel about their job (Currivan, 1999; Robbins \& Judge, 2007) and by the degree of positive emotions they display toward their work roles. Overall, job satisfaction measures are an accurate means to predict behavior, which in turn enables employees to regulate their assessment as to whether it is worthwhile to change any aspects of their behavior (Falkenburg \& Schyns, 2007; Lambert, Hogan, \& Barton, 2001).

Kuruüzüm et al. (2009) developed and tested a structural model of organizational commitment which postulated that a relationship exists between job involvement, job satisfaction and organizational commitment. Within the model, job involvement is related to organizational commitment, which in turn affects job satisfaction. They concluded that there is a significant relationship between job involvement and job satisfaction. In recent studies, Khan and Nemati (2011) and Yeh (2013) are unequivocal in their claim that job involvement has a significant positive impact on job satisfaction.

Whereas the aforementioned studies and others (see for example, Jang \& George, 2012; Yang, 2010), have measured job satisfaction as a single construct, we investigated whether there was an association between the intrinsic and extrinsic aspects of job satisfaction with job involvement. Thus, hypotheses three and four are proposed:

$\mathrm{H}_{3}$ : There is a positive association between Job Involvement and Job Satisfaction - Intrinsic.

$\mathrm{H}_{4}$ : There is a positive association between Job Involvement and Job Satisfaction - Extrinsic.

\subsection{Organizational commitment and job satisfaction}

Ineson et al. (2013) found statistically significant relationships between employees' job satisfaction and commitment to their organization, while in their hospitality-specific study of organizational commitment and job satisfaction, and using the MeyerAllen Organizational Commitment Scale, and the Minnesota Job Satisfaction Questionnaire, Gunlu, Aksarayli, and Percin (2010) suggest that extrinsic, intrinsic, and general job satisfaction have a significant effect on normative and affective commitment. However, the dimensions of job satisfaction do not have a significant effect on continuance commitment among employees of largescale hotels (Kuruüzüm et al., 2009). While Meyer, Stanley, Herscovitch, and Topolnytsky (2002) found a weak correlation between affective commitment and job satisfaction, much of the research has focused on job satisfaction's impact on organizational commitment (Testa, 2001). However, Namasivayam and Zhao (2007), and Yousef (2000) have found that organizational commitment can lead to job satisfaction. Accordingly, and in line with the extant literature, the following hypotheses are proposed:

$\mathrm{H}_{5}$ : There is a positive association between Organizational Commitment - Affective and Job Satisfaction - Intrinsic.

$\mathrm{H}_{6}$ : There is a positive association between Organizational Commitment - Affective and Job Satisfaction - Extrinsic.

$\mathrm{H}_{7}$ : There is a positive association between Organizational Commitment - Normative and Job Satisfaction - Intrinsic.

$\mathrm{H}_{8}$ : There is a positive association between Organizational Commitment - Normative and Job Satisfaction - Extrinsic.

\subsection{Organizational commitment and labor turnover}

Labor turnover has been defined as “...the voluntary and involuntary permanent withdrawal from an organization" (Robbins \& Judge, 2007, p. 72). Lingard (2003) suggests that it is very difficult to measure actual turnover behavior, but concludes that intention to turnover is a good and reliable predictor of actual turnover behavior. Intention to quit is the immediate precursor of actual withdrawal behavior (Iverson \& Deery, 1997; Jang \& George, 2012), while Steel and Ovalie (1984), and Yang, Wan, and Fu (2012) suggest that in order to predict whether employees will leave an organization it is necessary to identify their commitment to stay. The interest in organizational commitment from academe has highlighted the positive relationship between it and organizational effectiveness, which also includes a negative relationship with turnover (Yin-Fah, Foon, Chee-Leong, \& Osman, 2010). Organizational commitment's role as a predictor of turnover intention also informed the work of Joo and Park (2009) which investigated aspects of job satisfaction, and learning and development in 


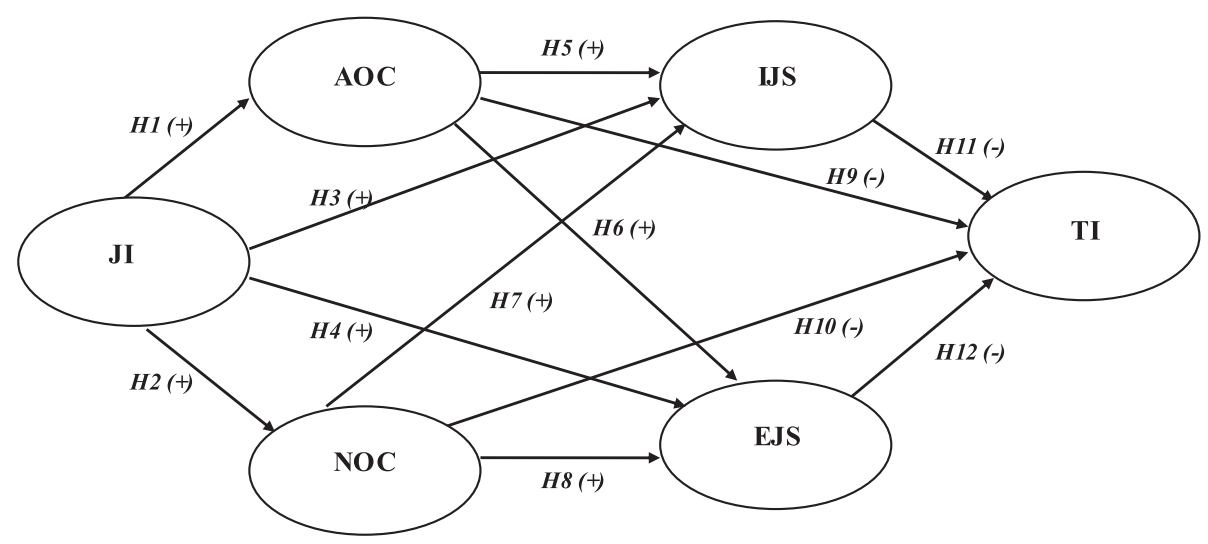

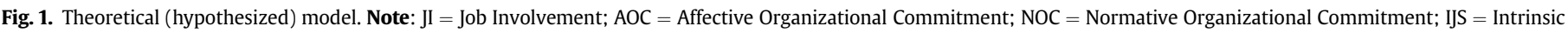
Job Satisfaction; EJS = Extrinsic Job Satisfaction; TI = Turnover Intention.

organizations. In a similar vein Fulford (2005) and Cho, Johanson, and Guchait (2009) propose a robust argument that organizational commitment is negatively related to turnover intention, while Gunlu et al. (2010) are unequivocal in their argument that both affective and normative commitment have a significant effect on turnover intention (see also Carbery et al., 2003; Culpepper, 2011; Kuruüzüm et al., 2009; Labatmediene, Endriulaitiene, \& Gustainiene, 2007; Nadiri \& Tanova, 2010; Namasivayam \& Zhao, 2007; Yang, 2010). On the basis of the above theoretical elements the following hypotheses are proposed:

$\mathrm{H}_{9}$ : There is a negative association between Organizational Commitment - Affective and Turnover Intention.

$\mathrm{H}_{10}$ : There is a negative association between Organizational Commitment - Normative and Turnover Intention.

\subsection{Job satisfaction and labor turnover}

In their seminal work investigating job satisfaction and turnover intention, Ghiselli, La Lopa, and Bai (2001) suggest that the majority of those indicating an intent to leave the organization, are more likely to leave the industry altogether. Their insightful analysis and subsequent conclusions are unequivocal, informing us that employees are influenced more by intrinsic satisfaction in the shortterm. The implication being that if intrinsic needs continue to be unmet, extrinsic satisfaction will then influence long-term turnover intentions. Others have echoed similar conclusions (Karatepe, Avci, Karatepe, \& Canozer, 2003; Karatepe, Uludag, Menevis, Hadzimehmedagic, \& Baddar, 2006; Lam, Zhang, \& Baum, 2001), with Poe (2003) arguing that organizations focusing on the intrinsic aspects of job satisfaction are more likely to minimize hotel employee attrition and turnover. In other words intrinsic and extrinsic factors of job satisfaction are both significant determinants of intention to leave, suggesting that organizations are failing to retain their employees by not providing them with adequate authority, responsibility, job security and variety.

Investigating job satisfaction and turnover intention, Karatepe et al. (2006) found a negative association between the two constructs, while in their study of head chefs of casino hotels, Chuang, Yin, and Dellman-Jenkins (2008) investigated the extrinsic and intrinsic factors of job satisfaction. Furthermore, the aforementioned scholars found that the nature of the work was a major contributor to the chefs' job satisfaction, while recognition was a source of low satisfaction, and elements such as paid vacations, salary and sick leave were sources of dissatisfaction. Others have suggested that these extrinsic factors have driven employees to seek alternative employment (Kosmoski, 1997; O'Leary \& Deegan, 2005). Accordingly, and informed by the literature, the following two hypotheses are proposed in order to shed some light on the association between job satisfaction and turnover intention:

$\mathrm{H}_{11}$ : There is a negative association between Job Satisfaction Intrinsic and Turnover Intention.

$\mathrm{H}_{12}$ : There is a negative association between Job satisfaction Extrinsic and Turnover Intention.

\subsection{Hypothesized model}

Reflecting the literature and the postulated hypotheses, a theoretical model was developed, exhibited in Fig. 1, which depicts in an integrated manner the causal relationships of employee's job involvement, commitment, satisfaction and turnover intention. Despite the fact that the individual relationships between each of the six constructs have been investigated in the past, only a handful of empirical papers have attempted to investigate it holistically.

\section{Research methodology and design}

The primary objective of the study was to investigate in an integrated manner the association of job involvement, organizational commitment (normative and affective), and job satisfaction (intrinsic and extrinsic) with the turnover intention of hospitality employees currently working in Cyprus. Based on this rationale, deductive reasoning (from the general to the specific) was utilized in order to narrow down the theory presented in the literature to the twelve hypotheses (only alternative hypotheses are stated) presented in the previous section.

\subsection{Methodology}

The thorough review of the literature enabled the development of a quantitative questionnaire with the aim of addressing the postulated hypotheses. The survey was translated, and backtranslated, by a linguist with expertise in both the English and Greek languages in order to ensure terminological accuracy. The research instrument consisted of three distinct sections. The first section, adopting the Minnesota Job Satisfaction Questionnaire (MSQ - short form), measured job satisfaction, where respondents were asked to express their level of satisfaction on 18 specific job aspects with the utilization of a 5-point Likert scale ranging from 1 being not satisfied to 5 extremely satisfied. The second included the tools measuring job involvement, job commitment and turnover 
intention, where again a 5-point Likert scale ( 1 = strongly disagree to $5=$ strongly agree), was utilized to measure the respondents' views on the specific job-related issues under investigation. Finally, the third section included demographic and other backgroundrelated questions that would enable a more thorough analysis of the data.

A simple random sample of 1500 questionnaires was administered during a six-month period (April-September) to individuals working full-time in 3-, 4- and 5-star hotels in Cyprus. According to figures made available by government agencies and local hospitality associations, 15,000 individuals are currently employed by the industry as full-time employees. Mindful of the typical low response rate in hospitality-related studies in Cyprus, a mixed approach was utilized in order to increase the number of responses. This included traditional mail, followed by a telephone reminder and direct survey distribution by hand. Prior to administration, the questionnaires were pilot-tested for reliability using the test re-test method, with Cronbach's reliability coefficient $\alpha$ scores exceeding 0.7 , the minimum acceptable as suggested by Nunnally and Bernstein (1994). The content validity of the questionnaire was examined by a panel of experts prior to their administration, culminating in data analysis.

With the utilization of AMOS (v.20) software, structural equation modeling (SEM), a multivariate statistical analysis method that can explore hypothesized relationships in an integrated manner, was conducted with a sample of 482 hospitality full-time employees. SEM has gained notable recognition by tourism scholars in the last decade as a reliable and valid method, for determining whether relationships exist between constructs as a means to either accept or reject a hypothesized theory. It is important to note that the ratio between the sample size and the number of observed variables in the hypothesized model, a priori criterion for the Maximum Likelihood (ML) estimation, is higher than 10 to 1 which according to Thompson (2000) is ideal for such an analysis. The hypothesized model measured six latent (unobserved) variables labeled as: (1) Job Involvement (JI), (2) Affective Organizational Commitment (AOC), (3) Normative Organizational Commitment (NOC), (4) Intrinsic Job Satisfaction (IJS), (5) Extrinsic Job Satisfaction (EJS), and (6) Turnover Intention (TI).

\subsection{Measurement tools}

Three existing tools were utilized for the purposes of the study. Specifically, Kanungo's (1982) tool was used to measure job involvement, whereas Meyer and Allen's (1991) tool measured both normative and affective organizational commitment, and finally, the Minnesota Job Satisfaction Questionnaire (MSQ - short form) measured job satisfaction. The criteria for adopting the particular tools includes their validity and reliability qualities, their prior utilization in hospitality and tourism-related studies and their

Table 1

Model items descriptive statistics (35 items).

\begin{tabular}{|c|c|c|c|c|c|}
\hline Construct & Source & Item's label & Question item & Std dev. & Mean \\
\hline \multirow[t]{8}{*}{ Job Involvement (JI) } & \multirow[t]{8}{*}{ (Kanungo, 1982) } & JI1 & I like to be absorbed in my job most of the time: & 0.996 & 3.28 \\
\hline & & JI2 & I consider my job to be very central (important) to my existence: & 1.074 & 3.39 \\
\hline & & JI3 & Most of my personal life goals are job oriented: & 1.024 & 3.13 \\
\hline & & JI4 & $\begin{array}{l}\text { I have very strong ties with my present job which } \\
\text { would be very difficult to break: }\end{array}$ & 1.034 & 3.22 \\
\hline & & JI5 & Most of my interests are centered around my job: & 1.079 & 3.04 \\
\hline & & JI6 & I live, eat, and breathe my job: & 1.160 & 2.95 \\
\hline & & JI7 & I am very much personally involved in my job: & 1.012 & 3.44 \\
\hline & & JI8 & The most important things that happen to me involve my present job: & 0.918 & 3.17 \\
\hline \multirow{5}{*}{$\begin{array}{l}\text { Normative Organizational } \\
\text { Commitment (NOC) }\end{array}$} & \multirow[t]{5}{*}{ (Meyer \& Allen, 1991) } & NOC1 & I would feel guilty if I left this organization now: & 1.113 & 3.16 \\
\hline & & NOC2 & I feel a personal responsibility to continue working for this organization: & 1.024 & 3.22 \\
\hline & & NOC3 & $\begin{array}{l}\text { If I got another offer for a better job elsewhere, I would not feel } \\
\text { it was right for me to leave my organization: }\end{array}$ & 1.081 & 3.22 \\
\hline & & NOC4 & It would not be morally right for me to leave this company now: & 1.056 & 3.41 \\
\hline & & NOC5 & $\begin{array}{l}\text { Even if it were to my advantage, I do not feel it would be right to } \\
\text { leave my organization now: }\end{array}$ & 1.068 & 3.37 \\
\hline \multirow[t]{3}{*}{$\begin{array}{l}\text { Affective Organizational } \\
\text { Commitment (AOC) }\end{array}$} & \multirow[t]{3}{*}{ (Meyer \& Allen, 1991) } & AOC1 & $\begin{array}{l}\text { I would be very happy to spend the rest of my } \\
\text { career with this organization: }\end{array}$ & 1.090 & 3.15 \\
\hline & & AOC2 & I really feel as if this organization's problems are my own: & 1.049 & 3.06 \\
\hline & & AOC3 & This organization has a great deal of personal meaning for me: & 0.960 & 3.30 \\
\hline \multirow[t]{10}{*}{ Intrinsic Job Satisfaction (IJS) } & \multirow[t]{10}{*}{ (Weiss et al., 1967) } & IJS1 & The chance to do different things from time to time: & 1.070 & 3.50 \\
\hline & & IJS2 & The chance to be somebody in the community: & 1.026 & 3.59 \\
\hline & & IJS3 & Being able to do things that don't go against my conscience: & 0.985 & 3.63 \\
\hline & & IJS4 & The way my job provides for steady employment: & 1.057 & 3.64 \\
\hline & & IJS5 & The chance to do things for other people: & 0.948 & 3.86 \\
\hline & & IJS6 & The chance to tell people what to do: & 1.104 & 3.37 \\
\hline & & IJS7 & The chance to do something that makes use of my abilities: & 1.038 & 3.62 \\
\hline & & IJS8 & The freedom to use my own judgment: & 1.039 & 3.28 \\
\hline & & IJS9 & The chance to try my own methods of doing the job: & 1.069 & 3.30 \\
\hline & & IJS10 & The feeling of accomplishment I get from the job: & 1.015 & 3.45 \\
\hline \multirow[t]{6}{*}{ Extrinsic Job Satisfaction (EJS) } & \multirow[t]{6}{*}{ (Weiss et al., 1967) } & EJS1 & The praise I get for doing a good job: & 1.134 & 3.25 \\
\hline & & EJS2 & The chances for advancement on this job: & 1.188 & 3.03 \\
\hline & & EJS3 & My pay and the amount of work I do: & 1.144 & 2.98 \\
\hline & & EJS4 & The way company policies are put into practice: & 1.046 & 3.37 \\
\hline & & EJS5 & The competency of my supervisor in making decisions: & 1.018 & 3.74 \\
\hline & & EJS6 & The way my supervisor handles his/her workers: & 1.100 & 3.66 \\
\hline \multirow[t]{3}{*}{ Turnover Intention (TI) } & \multirow[t]{3}{*}{ (Study specific) } & TI1 & It is likely that I will actively look for a new job next year: & 1.166 & 2.77 \\
\hline & & TI2 & I often think about quitting this job: & 1.175 & 2.67 \\
\hline & & TI3 & I will probably look for a job next year: & 1.188 & 2.71 \\
\hline
\end{tabular}

Scale: Job SatisfactionJ: 1 = not satisfied; $2=$ somewhat satisfied; $3=$ satisfied; $4=$ very satisfied; $5=$ extremely satisfied.

Scale: all other: $1=$ strongly disagree; $2=$ disagree; $3=$ neither agree nor disagree/neutral; $4=$ agree; $5=$ strongly agree.

Note: numerous variables have been removed due to exhibited factor loading of less than 0.5 . 
practicality in terms of time needed to administer them. To our knowledge this is the first time that the particular tools have been combined to investigate human resource-related issues in the hospitality industry.

\subsubsection{Job involvement}

Kanungo's 10 -item scale, propounded in 1982, reliably measures job involvement and has been used in social science studies (see for example, Blau, 1985; Elloy, Everett, \& Flynn, 1991). The hospitality literature highlighted its extensive use in recent investigations, by, for example, Kuruüzüm et al. (2009), and Crawford and Hubbard (2008).

\subsubsection{Organizational commitment (normative and affective)}

The Meyer and Allen (1991) survey instrument contained items measuring both affective and normative organizational commitment. The validity and reliability of the tool has been confirmed by numerous scholars (see for example, Joo \& Park, 2009; Stallworth, 2004), including hospitality-and tourism-specific studies (see for example, Carbery et al., 2003; Gunlu et al., 2010; Karatepe \& Kilic, 2007; Namasivayam \& Zhao, 2007).

\subsubsection{Job satisfaction (Minnesota job satisfaction)}

The Job Satisfaction Questionnaire was derived from the Minnesota studies on vocational rehabilitation as a measure of work adjustment (Weiss, Dawis, England, \& Lofquist, 1967). It measures both intrinsic elements, individual's feelings related to the nature of the job, and extrinsic elements, aspects that are separated from the work itself such as conditions of work and pay. The particular survey has been extensively utilized in hospitality studies (see for example, Ghiselli et al., 2001; Gunlu et al., 2010; Hancer \& George, 2003) with adequate reliability and validity qualities.

\subsubsection{Turnover intention}

Finally, for the study's dependent variable, turnover intention, a three-item study-specific tool was developed and administered. Turnover intention has been reliably measured by smaller tools of 3-5 items in numerous studies (see for example, Konovsky \& Cropanzano, 1991; O'Reilly, Chatman, \& Caldwell, 1991).

The 35 items, measuring the six latent variables as included in the final model, are exhibited in Table 1 in the form of descriptive statistics.

\section{Results}

\subsection{Sample characteristics}

Of the 1500 questionnaires distributed, four hundred and eighty two $(n=482)$ valid questionnaires were completed and returned, thus achieving a response rate of $32.13 \%$. Surveys of issues which some perceive as both sensitive and somewhat controversial, have a tendency toward lower response rates (Keegan \& Lucas, 2005). Subsequently, and comparing the overall response rate with previous research studies conducted in Cyprus, a response rate $>30 \%$ can be considered satisfactory (see for example, Theocharous \& Philaretou, 2009; Zopiatis \& Constanti, 2007, 2010). Table 1 exhibits the demographic profile of the respondents according to the variables of gender, age, nationality, current employer, educational background, and level of employment (Table 2).

\subsection{Measurement model evaluation}

Goodness-of-fit measures were utilized to assess the structural fit of the hypothesized model. Theory suggests that if the chisquare is not significant the model is regarded as acceptable,
Table 2

Demographic profile of the respondents $(n=482)$.

\begin{tabular}{|c|c|c|}
\hline & Frequency $^{\mathrm{a}}$ & $\begin{array}{l}\text { Valid } \\
\text { percentage }\end{array}$ \\
\hline \multicolumn{3}{|l|}{ Gender } \\
\hline$\overline{\text { Male }}$ & 231 & 47.9 \\
\hline Female & 251 & 52.1 \\
\hline \multicolumn{3}{|l|}{ Age } \\
\hline$\overline{18-30}$ & 222 & 46.3 \\
\hline $31-40$ & 147 & 30.6 \\
\hline $41-50$ & 80 & 16.7 \\
\hline Over 50 & 31 & 6.5 \\
\hline \multicolumn{3}{|l|}{ Nationality } \\
\hline$\overline{\text { Cypriot }}$ & 242 & 50.2 \\
\hline Non-Cypriot (migrant worker) & 240 & 49.8 \\
\hline \multicolumn{3}{|l|}{ Current employer } \\
\hline Hotel 5 star & 166 & 34.7 \\
\hline Hotel 4 star & 278 & 58.2 \\
\hline Hotel 3 star & 34 & 7.1 \\
\hline \multicolumn{3}{|l|}{ Educational background } \\
\hline$\overline{\text { High school graduate }}$ & 203 & 42.6 \\
\hline $\begin{array}{l}\text { College/university - diploma } \\
\text { (Associate Degree, HND, etc.) }\end{array}$ & 139 & 29.2 \\
\hline $\begin{array}{l}\text { College/university - Bachelor Degree } \\
\text { (BSc, BA, etc.) }\end{array}$ & 102 & 21.4 \\
\hline Graduate degree - Master's Degree & 29 & 6.1 \\
\hline Other & 3 & 0.6 \\
\hline \multicolumn{3}{|l|}{ Employment level } \\
\hline$\overline{\text { Entry level }}$ & 325 & 71.4 \\
\hline Middle level (supervisory) & 106 & 23.3 \\
\hline Upper level (top administration) & 24 & 5.3 \\
\hline
\end{tabular}

a Some demographic questions were not answered by all participants, thus, the variation in the actual frequency number.

nevertheless many disregard this since chi-square is often reported as significant mainly due to sample size restrictions and its sensitivity to the likelihood test ratio (Bentler \& Bonett, 1980). The model yielded a $\chi^{2}$ value of 1441.572 with 534 degrees of freedom $(p=0.000)$. In response to chi-square's in built limitations, the CMIN/DF fit ( $\chi^{2}$ divided by the degrees of freedom) surfaced as the more appropriate fit statistic with values less than 3 indicating an acceptable fit (Tabachnick \& Fidell, 2007). The final model revealed an acceptable CMIN/DF of 2.700 .

In terms of additional fit statistics, the model yielded a Root Mean Square Error of Approximation (RMSEA) of 0.059 (below the acceptable threshold of 0.070 , as suggested by Steiger, 2007), with a lower boundary of a two-sided $90 \%$ confidence interval for the population of 0.056 and an upper boundary of 0.063 . Moreover, the model produced a CFI (Comparative Fit Index) score 0.901, and an IFI (Incremental Fit Index) score 0.902; all falling within the ideal ranges ( $>0.90$ ) for acceptable fit (Hair, Black, Babin, \& Anderson, 2010). Finally, parsimonious fit indices such as PRATIO (0.897) and PCFI (0.809) also indicate an acceptable fit [Mulaik et al., 1989 suggest that the more complex the model, the lower the fit index]. Many scholars suggest a CFI and IFI threshold of $>0.95$ for accepting a model. Nevertheless, as suggested by Hair et al. (2010), both the complexity of the observed variables and the number of observations affect fit indices. The literature suggests that for models with more than 250 observations and with 30 or more observed variables a CFI above 0.900 in conjunction with an RMSEA of less than 0.070 , both the cases in our final model, suggest an acceptable fit.

Following the goodness-of-fit measurements which indicated an acceptable fit, a number of measurements were conducted with the aim of assessing the construct validity of the proposed theory. 
Table 3

Model's convergent validity qualities.

\begin{tabular}{|c|c|c|c|c|c|c|c|c|c|}
\hline & F1 (JI) & $\mathrm{F} 2(\mathrm{AOC})$ & F3 (NOC) & $\mathrm{F} 4$ (EJS) & F5 (IJS) & F6 (TI) & $\begin{array}{l}\text { Item reliabilities or squared } \\
\text { factor loadings (communalities) }\end{array}$ & Eigenvalue & $\begin{array}{l}\text { Delta (standardized } \\
\text { error variance) }\end{array}$ \\
\hline JI1 & 0.677 & & & & & & 0.458329 & & 0.541671 \\
\hline JI2 & 0.637 & & & & & & 0.405769 & & 0.594231 \\
\hline JI3 & 0.571 & & & & & & 0.326041 & & 0.673959 \\
\hline JI4 & 0.739 & & & & & & 0.546121 & & 0.453879 \\
\hline JI5 & 0.766 & & & & & & 0.586756 & & 0.413244 \\
\hline JI6 & 0.714 & & & & & & 0.509796 & & 0.490204 \\
\hline JI7 & 0.595 & & & & & & 0.354025 & & 0.645975 \\
\hline JI8 & 0.570 & & & & & & 0.324900 & 3.511737 & 0.675100 \\
\hline AOC1 & & 0.885 & & & & & 0.780000 & & 0.216775 \\
\hline $\mathrm{AOC} 2$ & & 0.660 & & & & & 0.435600 & & 0.564400 \\
\hline AOC3 & & 0.792 & & & & & 0.627264 & 1.846089 & 0.372736 \\
\hline NOC1 & & & 0.826 & & & & 0.682276 & & 0.317724 \\
\hline NOC2 & & & 0.850 & & & & 0.722500 & & 0.277500 \\
\hline NOC3 & & & 0.718 & & & & 0.515524 & & 0.484476 \\
\hline NOC4 & & & 0.703 & & & & 0.494209 & & 0.505791 \\
\hline NOC5 & & & 0.716 & & & & 0.512656 & 2.927165 & 0.487344 \\
\hline EJS1 & & & & 0.702 & & & 0.492804 & & 0.507196 \\
\hline EJS2 & & & & 0.781 & & & 0.609961 & & 0.390039 \\
\hline EJS3 & & & & 0.687 & & & 0.471969 & & 0.528031 \\
\hline EJS4 & & & & 0.714 & & & 0.509796 & & 0.490204 \\
\hline EJS5 & & & & 0.632 & & & 0.399424 & & 0.600576 \\
\hline EJS6 & & & & 0.642 & & & 0.412164 & 2.896118 & 0.587836 \\
\hline IJS1 & & & & & 0.641 & & 0.410881 & & 0.589119 \\
\hline IJS2 & & & & & 0.705 & & 0.497025 & & 0.502975 \\
\hline IJS3 & & & & & 0.535 & & 0.286225 & & 0.713775 \\
\hline IJS4 & & & & & 0.609 & & 0.370881 & & 0.629119 \\
\hline IJS5 & & & & & 0.515 & & 0.265225 & & 0.734775 \\
\hline IJS6 & & & & & 0.624 & & 0.389376 & & 0.610624 \\
\hline IJS7 & & & & & 0.710 & & 0.504100 & & 0.495900 \\
\hline IJS8 & & & & & 0.711 & & 0.505521 & & 0.494479 \\
\hline IJS9 & & & & & 0.660 & & 0.435600 & & 0.564400 \\
\hline IJS10 & & & & & 0.751 & & 0.564001 & 4.228835 & 0.435999 \\
\hline TI1 & & & & & & 0.872 & 0.760384 & & 0.239616 \\
\hline $\mathrm{TI} 2$ & & & & & & 0.808 & 0.652864 & & 0.347136 \\
\hline $\mathrm{TI} 3$ & & & & & & 0.886 & 0.784996 & 2.198244 & 0.215004 \\
\hline Variance extracted & $47.97 \%$ & $61.54 \%$ & $58.54 \%$ & $48.27 \%$ & $42.29 \%$ & $73.27 \%$ & & & \\
\hline Construct reliability & $86.08 \%$ & $82.56 \%$ & $87.52 \%$ & $84.78 \%$ & $\mathbf{8 7 . 8 5 \%}$ & $89.15 \%$ & & & \\
\hline
\end{tabular}

Note: model's average variance extracted $(\mathbf{A V E})=\mathbf{0 . 5 5}$.

The construct validity, the extent to which the measured items actually reflect the theoretical latent construct proposed, was evaluated in terms of convergent validity. As exhibited in Table 3, the conditions for convergent validity, the extent to which indicators of a specific construct share a high proportion of common variance, were satisfied based on factor loadings (all $>0.50$ ), average variance extracted (AVE > 0.50; Bagozzi \& Yi, 1988) and reliability $(>0.70)$. In particular, the overall AVE for the model is 0.55 , whereas reliability scores range from 0.82 to 0.89 .

\subsection{Structural model and hypotheses testing}

Standardized path coefficients and the significance of the hypothesized relationships were utilized to test the postulated hypotheses in a causal diagrammatic form (see Fig. 2). Findings suggest that both $\mathrm{H}_{1}$ and $\mathrm{H}_{2}$ can be supported since positive associations were revealed between job involvement and affective organizational commitment $\left(\mathrm{H}_{1}\right)$ (standardized path coefficient $\beta=0.597 ; p<0.01$ ), and job involvement and normative organizational commitment $\left(\mathrm{H}_{2}\right)$ (standardized path coefficient $\beta=0.722$; $p<0.01)$. The third hypothesis, a positive association between job involvement and intrinsic job satisfaction can be supported from the findings (standardized path coefficient $\beta=0.186 ; p<0.05$ ), whereas no significant associate was revealed pertaining to our fourth hypothesis (standardized path coefficient $\beta=0.147$; n.s.) which assumed a positive association between job involvement and extrinsic job satisfaction.
Hypotheses five and six are supported since positive associations were revealed between affective organizational commitment, and both intrinsic job satisfaction $\left(\mathrm{H}_{5}\right)$ (standardized path coefficient $\beta=0.278 ; p<0.01)$, and extrinsic job satisfaction $\left(\mathrm{H}_{6}\right)$ (standardized path coefficient $\beta=0.410 ; p<0.01$ ). Similarly, when investigating the association between normative organizational commitment and job satisfaction $\left(\mathrm{H}_{7}\right.$ and $\left.\mathrm{H}_{8}\right)$, significant positive associations were revealed with intrinsic job satisfaction (standardized path coefficient $\beta=0.245 ; p<0.01$ ) and extrinsic job satisfaction (standardized path coefficient $\beta=0.271 ; p<0.01$ ).

When investigating turnover intention, only two out of the four related hypotheses can be supported. In particular, a negative association between affective organizational commitment $\left(\mathrm{H}_{9}\right)$ (standardized path coefficient $\beta=-0.138 ; p<0.05$ ), can be supported, whereas $\mathrm{H}_{10}$, the hypothesized negative association between normative organizational commitment and turnover intention cannot be supported (standardized path coefficient $\beta=0.044$; n.s.). Moreover, a negative association can be supported between extrinsic job satisfaction and turnover intention $\left(\mathrm{H}_{12}\right)$ (standardized path coefficient $\beta=-0.317 ; p<0.05$ ), whereas the hypothesized negative association between intrinsic job satisfaction and turnover intention $\left(\mathrm{H}_{11}\right)$ (standardized path coefficient $\beta=-0.021$; n.s.) cannot. Challenging conventional norms (see for example, Karatepe et al., 2006; Poe, 2003), no association, either positive or negative, was revealed between intrinsic job satisfaction traits and turnover intention. This is discussed further in the subsequent section. 


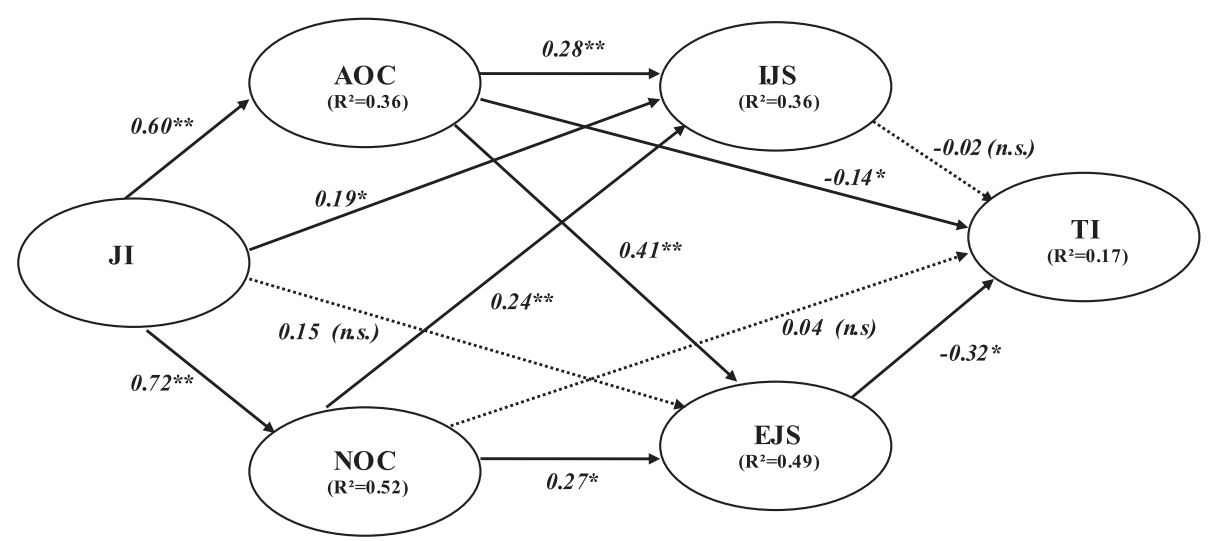

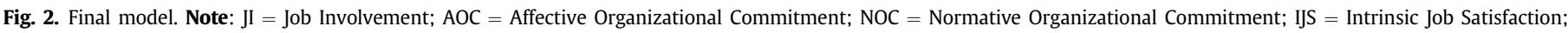
EJS = Extrinsic Job Satisfaction; TI $=$ Turnover Intention. ${ }^{*}$ Significant at $p<0.05 ;{ }^{* *}$ significant at $p<0.01$; n.s. $=$ non-significant (dotted lines indicate non-significant paths).

Overall, the analysis, exhibited in Table 4, revealed that nine of the postulated hypotheses can be accepted, whereas Hypotheses 4, 10 and 11 cannot be supported.

Finally, the model was also tested for mis-specifications with the utilization of modification indices. With regard to the standardized residuals, none of the produced values exceed the cut-off point of 2.58 (Hair et al., 2010), whereas all maximum likelihood estimates were found to have a critical ratio of $> \pm 1.96$, thus suggesting a 0.05 level of significance (Hoyle, 1995). Moreover, several suggestions for loosening constraints on certain parameters, which were theoretically meaningful, were adapted from modification indices.

\section{Discussion and conclusions}

The study examined the association between job involvement, organizational commitment (normative and affective) and, job satisfaction (intrinsic and extrinsic) with the turnover intention of hospitality employees working in Cyprus. Despite the plethora of evidence, which in many cases is somewhat anecdotal in nature, our study challenges some conventional norms, particularly within the Cypriot hospitality and tourism research landscape. The utilization of structural equation modeling enabled us to gain an indepth holistic perspective of the causal linkages of the aforementioned constructs within the hospitality landscape.

While trawling through the literature it was evident that many of the studies (re)iterated the mantra that highly-job-involved individuals exhibit high levels of organizational commitment and are less likely to quit their organization (e.g., Ineson et al., 2013; Kuruüzüm et al., 2009; Rotenberry \& Moberg, 2007). The findings supported the hypotheses that there is a positive association between job involvement and both affective and normative organizational commitment, also affirming the work of Kuruüzüm et al. (2009). This evidence suggests that organizations concerned about employee commitment should instigate policies and practices that further involve those at the 'coal-face' including informationsharing, decision-making and empowerment initiatives which can win 'hearts and minds'. Anecdotal evidence would suggest that this is rarely the norm, where the tendency is for top-down command and control organizational structures and practices (Zopiatis \& Constanti, 2007). Emotional connections with the organization are manifested through affective and normative forms of organizational commitment. Employees feel a sense of belonging, while also believing that they have a moral or ethical obligation to stay as they continue to work toward achieving organizational goals.

When investigating the causal relationships between job involvement and both extrinsic and intrinsic job satisfaction, a significant association was revealed only with the later. It seems that job involvement impacts individuals' feelings regarding the nature of their job tasks, but not on other external job aspects. Our findings partially support other similar studies despite the fact that job satisfaction was measured as a single construct by other researchers. Moreover, it is suggested that this finding be viewed with an element of caution since the hypothesized positive association between job involvement and extrinsic job satisfaction was marginally rejected ( $p=0.076 ; t=1.773$ ), which leads us to suggest the need for a more robust investigation in order to establish an unequivocal conclusion.

The theories proclaim that aspects and elements of the work itself will promote satisfaction and feelings of affiliation to the workplace (Robbins \& Judge, 2007). Subsequently, our investigation measured the intrinsic and extrinsic traits of job satisfaction separately and we found that there is a positive association between them and both affective and normative organizational commitment, sharing similarities with other studies (Namasivayam \& Zhao, 2007; Yousef, 2000) which found that organizational commitment leads to job satisfaction. The study's utilization of structural equation modeling, examining intrinsic and extrinsic job satisfaction separately, provided further, more robust evidence of the relationships between the two constructs, coinciding with Meyer et al. (2002) who concluded that both constructs "should be considered in efforts to understand and manage employee behavior" (p. 38).

In all measurements, affective organizational commitment was more strongly associated with both intrinsic and extrinsic job

Table 4

Summary of hypotheses and results.

\begin{tabular}{llll}
\hline Hypotheses & $\begin{array}{l}\text { Standardized } \\
\text { path coefficient }\end{array}$ & $t$-Value & Results \\
\hline $\mathrm{H}_{1}: \mathrm{JI} \rightarrow(+)$ AOC & 0.597 & $10.647^{* *}$ & Accepted \\
$\mathrm{H}_{2}: \mathrm{JI} \rightarrow(+)$ NOC & 0.722 & $12.195^{* *}$ & Accepted \\
$\mathrm{H}_{3}: \mathrm{JI} \rightarrow(+) \mathrm{IJS}$ & 0.186 & $2.154^{*}$ & Accepted \\
$\mathrm{H}_{4}: \mathrm{JI} \rightarrow(+)$ EJS & 0.147 & 1.773 (n.s.) & Cannot be supported \\
$\mathrm{H}_{5}: \mathrm{AOC} \rightarrow(+)$ IJS & 0.278 & $4.507^{* *}$ & Accepted \\
$\mathrm{H}_{6}: \mathrm{AOC} \rightarrow(+)$ EJS & 0.410 & $6.733^{* *}$ & Accepted \\
$\mathrm{H}_{7}: \mathrm{NOC} \rightarrow(+)$ IJS & 0.245 & $3.319^{* *}$ & Accepted \\
$\mathrm{H}_{8}: \mathrm{NOC} \rightarrow(+)$ EJS & 0.271 & $3.803^{* *}$ & Accepted \\
$\mathrm{H}_{9}: \mathrm{AOC} \rightarrow(-) \mathrm{TI}$ & -0.138 & $-2.008^{*}$ & Accepted \\
$\mathrm{H}_{10}: \mathrm{NOC} \rightarrow(-) \mathrm{TI}$ & 0.044 & 0.470 (n.s.) & Cannot be supported \\
$\mathrm{H}_{11}: \mathrm{IJS} \rightarrow(-) \mathrm{TI}$ & -0.021 & 0.864 (n.s.) & Cannot be supported \\
$\mathrm{H}_{12}: \mathrm{EJS} \rightarrow(-) \mathrm{TI}$ & -0.317 & $-2.127^{*}$ & Accepted \\
\hline
\end{tabular}

Note: JI = Job Involvement; $\mathrm{AOC}=$ Affective Organizational Commitment NOC $=$ Normative Organizational Commitment; IJS = Intrinsic Job Satisfaction; EJS = Extrinsic Job Satisfaction; TI = Turnover Intention.

*Significant at $p<0.05$; ** significant at $p<0.01$; n.s. = non-significant. 
satisfaction compared to normative commitment. This suggests that employees with a positive emotional attachment to their organization will exhibit higher levels of satisfaction in their feelings about the job itself, as well as to other external aspects of the job. Individuals who identify with their organization and its goals are likely to exhibit commitment behaviors as a means to achieve their personal goals and subsequently attain higher levels of satisfaction with their work and outcomes. Organizations can maintain high levels of commitment, while addressing the intrinsic aspects of employee job satisfaction with policies and practices which both encourage and develop employee skills that add value. This does not imply that the extrinsic aspects should be ignored; on the contrary, strategic people management practices are necessary in order to influence employee behaviors that are aligned with organizational goals.

Scholars have called for additional investigations into the relationship of organizational commitment with turnover intention (see for example, Labatmediene et al., 2007). In accordance with Yang's (2010) findings, our data revealed a significant negative association between affective organizational commitment and turnover intention, in contrast with the Karatepe and Kilic (2007) study which could not substantiate such a claim. Furthermore, echoing the work of Gunlu et al. (2010), and similar to other hospitality industry studies (see for example, Carbery et al., 2003; Culpepper, 2011), our findings could not support a negative association between normative organizational commitment and an individual's turnover intention.

Finally, the study investigated the association of job satisfaction (both intrinsic and extrinsic) and turnover intention. Studies which claim a significant negative association between the two constructs (see for example, Jang \& George, 2012; Yang, 2010), have measured job satisfaction as a single construct, whereas we measured both the intrinsic and extrinsic traits. In environments challenged with issues such as seasonality, part-time employment, overdependence on migrant labor, job (in)security, lack of career advancement opportunities, and excessive turnover, intrinsic motives are most often obscured by the more 'materialistic' extrinsic job traits which seem to have a determining role influencing both the overall job satisfaction and turnover intention.

Findings revealed a significant negative association only between turnover intention and extrinsic job satisfaction, while intrinsic job satisfaction had neither a negative nor a positive association. That is to say, that the intrinsic aspects of job satisfaction revealed neither a positive nor a negative association with turnover intention, and yet the absence of extrinsic job satisfaction can increase turnover intention. Cyprus' characteristics as an island tourism destination may serve to clarify understanding as to why this is the case. The seasonal nature of the industry has been accompanied by a decrease in core, and the increase and greater reliance on peripheral staff. Consequently, employees are less loyal, while employers' obsession with cost reduction and short-termism reduces their motivation to invest in training and development of the workforce, whether core or peripheral in nature (see for example, Adler \& Adler, 2004; Baum \& Lundtorp, 2000; Baum et al., 2007; Conlin \& Baum, 2003; Shakeela \& Cooper, 2009).

In addition, Baum's (2012) lucid critique of 'adhocism' in most tourism-related enterprises' human resource management practices can also inform the discourse. This lackadaisical approach to managing people is likely to culminate in the squandering of an island's human capital with far reaching repercussions, particularly where economic development is dependent on the tourism sector. In essence, hospitality enterprises are 'bribing' their people (Pfeffer, 1998), and if the 'bribe' is not adequate, employees will seek out an employer with a more generous 'bribe'.
Findings of this study imply that in the midst of a global financial crisis, which brought severe hardship to numerous Mediterranean countries (e.g., Cyprus, Greece, Spain, Italy), intrinsic job satisfaction traits seems to take the 'back-stage' in employees' decisions. Moreover, some may contemplate that individual's turnover intention is a complex phenomenon in which existing theories, derived from hospitality studies, might not fully depict. It can be argued that existing models, which many times provide contradictory results, fail to fully grasp the essence of the hospitality employee's turnover intention. The uniqueness and specificity of the hospitality environment, volatile socio-economic circumstances, as well as, other 'uncontrollable' factors, may affect such an intention and reinforce a turnover culture with a multitude of effects for the industry. A need to further investigate such issues in different cultural contexts is also supported by Namasivayam and Zhao (2007).

\section{Industry implications and directions for future research}

Findings generated by SEM analysis may have implications for local hospitality stakeholders, especially those responsible for managing human resources. An enhanced understanding of elements that impact workplace attitudes (Judge \& KammeyerMueller, 2012) some of which challenge existing theoretical paradigms propounded in the specificity of particular environments will enable individuals to better understand and actively engage human resources issues. Reflecting the uniqueness of the Cyprus hospitality industry, the findings suggest that job involvement is more strongly associated with organizational commitment rather than job satisfaction. Additionally, extrinsic job satisfaction is related to turnover intention implying that managerial style and reward strategies present both challenges and opportunities to industry stakeholders. Hotel organizations must maintain constant surveillance regarding employee attitudes toward both the manner in which they are managed, and the manner in which they are rewarded. The failure of management to grasp the realities of life at the 'coal-face' is likely to aggravate turnover and the subsequent costs to operations.

Faced with the challenge of providing the appropriate environment where employees are engaged with their place of work, organizations must rise to the challenges that this implies. For example, they must be vigilant, as they execute and implement operational strategies and policies which will improve commitment to the organization, including the decentralization of decision-making and profit-sharing. They will be driven to answer the question, "What is the alternative to 'bribery' when rewarding my people?"

The study has provided further evidence of the particular characteristics that constitute 'Island Tourism'. However, the findings reveal further questions for future research, such as utilizing structural equation modeling in other island destinations, both in the region and further afield for comparison. This is required particularly with the aspects where we have highlighted contrary evidence with regard to job satisfaction and both affective organizational commitment and turnover intention. Not only would it be prudent to investigate whether there are more robust relationships between intrinsic and extrinsic job satisfaction, involvement, commitment and turnover, but more specifically we would explore the association between turnover intention and intrinsic job satisfaction. Last but not least, incorporating and including control variables that reflect the uniqueness of island destinations may also highlight some insightful revelations, both for practitioners and academe.

It was intended that the study would broaden our horizons as to the essential elements that if enhanced, have the potential of 
nurturing a positive organizational environment. To paraphrase Meyer et al. (2002), organizations are more likely to enhance commitment if they focus on carefully managing their employees' experiences following entry, instead of investing the bulk of their efforts on recruiting those who might be predisposed to being affectively committed.

\section{Limitations}

Despite some notable contributions, we would like to acknowledge specific limitations. Foremost, the homogeneity of the sample, consisting of hotel employees in Cyprus, and secondly, an island destination in the Mediterranean and a member of the EU, may limit the generalizability of the findings in other environments. Nevertheless, in spite of the aforementioned, we believe that we have provided some indicative evidence, even for the most discerning reader wishing to further investigate these aspects of workplace attitudes within the hospitality industry.

The conscious decision not to investigate continuance commitment was based on the literature which consistently indicated either a very weak or negligible association with other variables (see for example, Gunlu et al., 2010; Kuruüzüm et al., 2009; Meyer et al., 2002). Others may wish to revisit this element in order to (dis)prove this association, not only with job involvement, job satisfaction, and/or turnover intention, but also with the other commitment dimensions - affective and normative.

\section{References}

Adler, P. A., \& Adler, P. (2004). Paradise laborers: Hotel work in the global economy. Ithaca, NY: Cornell University Press.

Allen, N. J., \& Meyer, J. P. (1990). The measurement and antecedents of affective, continuance and normative commitment to the organization. Journal of Occupational Psychology, 63, 1-18.

Allport, G. (1943). The ego in contemporary psychology. Psychological Review, 50, 451-476.

Bagozzi, R. P., \& Yi, Y. (1988). On the evaluation of structural equation models. Journal of the Academy of Marketing Science, 16(1), 74-94.

Baum, T. (2007). Human resources in tourism: still waiting for change. Tourism Management, 1(28), 1383-1399.

Baum, T. (2012). Human resource management in tourism: a small island perspective. International Journal of Culture, Tourism and Hospitality Research, 6(2), 124-132

Baum, T., Hearns, N., \& Devine, F. (2007). Place, people and interpretation: issues of migrant labor and tourism imagery in Ireland. Tourism and Recreation Research, 32(3), 39-48.

Baum, T., \& Lundtorp, S. (2000). Seasonality in tourism. London: Elsevier.

Bentler, P. M., \& Bonett, D. G. (1980). Significant tests and goodness of fit in the analysis of covariance structures. Psychological Bulletin, 88, 588-606.

Birdir, K. (2002). General manager turnover and root causes. International Journal of Contemporary Hospitality Management, 14(1), 43-47.

Blau, G. (1985). A multiple study investigation of the dimensionality of job involvement. Journal of Vocational Behavior, 27, 19-36.

Carbery, R., Garavan, T. N., O’Brien, F., \& McDonnell, J. (2003). Predicting hotel managers' turnover cognitions. Journal of Managerial Psychology, 18(7), 649-679.

Cho, S., Johanson, M. M., \& Guchait, P. (2009). Employees intent to leave: a comparison of determinants of intent to leave versus intent to stay. International Journal of Hospitality Management, 28(3), 374-381.

Chuang, N.-K... Yin, D., \& Dellman-Jenkins, M. (2008). Intrinsic and extrinsic factors impacting casino hotel chefs' job satisfaction. International Journal of Contemporary Hospitality Management, 21(3), 323-340.

Clerides, S., \& Pashourtidou, N. (2007). Tourism in Cyprus: recent trends and lessons from the tourist satisfaction survey. Cyprus Economic Policy Review, 1(2), $51-72$.

Cohen, A. (2000). The relationship between commitment forms and work outcomes: a comparison of three models. Human Relations, 53(3), 387-417.

Conlin, M., \& Baum, T. (2003). Comprehensive human resource planning: an essential key to sustainable tourism in island settings. In C. Cooper (Ed.), Classic reviews in tourism (pp. 115-129). Clevedon: Channel View Publications.

Crawford, A., \& Hubbard, S. (2008). The impact of work-related goals on hospitality industry employee variables. Tourism and Hospitality Research, 8(2), $116-124$.

Culpepper, R. A. (2011). Three-component commitment and turnover: an examination of temporal aspects. Journal of Vocational Behavior, 79(2), 517-527.
Currivan, D. B. (1999). The causal order of job satisfaction and organizational commitment in models of employee turnover. Human Resource Management Review, 9(4), 495-524.

Cyprus Tourism Organization. Annual report 2011. Retrieved 14.10.12, from http:/ media.visitcyprus.com/media/b2b_gr/CTOAnnualReports/Annual_Report_2011. pdf.

Davidson, M. C. G., Timo, N., \& Wang, Y. (2010). How much does labour turnover cost? A case study of Australian four and five-star hotels. International Journal of Contemporary Hospitality Management, 22(4), 451-466.

Deery, S., Iverson, R., \& Walsh, J. (2002). Work relationships in telephone call centers: understanding emotional exhaustion and employee withdrawal. Journal of Management Studies, 39(4), 472-496.

Dubin, R. (1956). Industrial workers' world: a study of the central life interests of industrial workers. Social Problems, 3, 131-142.

Elloy, D. F., Everett, J. E., \& Flynn, W. R. (1991). An examination of the correlates of job involvement. Group and Organization Studies, 16(2), 160-177.

Falkenburg, K., \& Schyns, B. (2007). Work satisfaction, organizational commitment and withdrawal behaviors. Management Research News, 30(10), 708-723.

Fulford, M. D. (2005). That's not fair! The test of a model of organizational justice, job satisfaction, and organizational commitment among hotel employees. Journal of Human Resources in Hospitality E Tourism, 4(1), 73-84.

Garín-Munõz, T., \& Montero-Martin, L. F. (2007). Tourism in the Balearic Islands: a dynamic model for international demand using panel data. Tourism Management, 28(5), 1224-1235.

Ghiselli, R. F., La Lopa, J. M., \& Bai, B. (2001). Job satisfaction, life satisfaction, and turnover intent among food-service managers. Cornell Hotel and Restaurant Administration Quarterly, 42(2), 28-37.

Gordon, M., Philpot, J., Burt, R., Thompson, C., \& Spiller, W. (1980). Commitment to unions: development of a measure and an examination of its correlates. Journal of Applied Psychology, 65, 479-499.

Greenhaus, J. (1971). An investigation of the role of career salience in vocational behavior. Journal of Vocational Behavior, 1, 209-216.

Gronroos, C. (2000). Service management and marketing: A customer relationship management approach. New York, NY: John Wiley and Sons.

Gunlu, E., Aksarayli, M., \& Percin, N. S. (2010). Job satisfaction and organizationa commitment of hotel managers in Turkey. International Journal of Contemporary Hospitality Management, 2(5), 693-717.

Hackett, R. D., Bycio, P., \& Hausdorf, A. (1994). Further assessments of Meyer and Allen's (1991) three component model of organizational commitment. Journal of Applied Psychology, 79(1), 15-23.

Hair, J. F., Jr., Black, W. C., Babin, B. J., \& Anderson, R. E. (2010). Multivariate date analysis (7th ed.). New Jersey: Pearson Prentice Hall.

Hancer, M., \& George, R. T. (2003). Job satisfaction of restaurant employees: an empirical investigation using the Minnesota satisfaction questionnaire. Journal of Hospitality \& Tourism Research, 27(1), 85-100.

Hartmann, L. C., \& Bambacas, M. (2000). Organizational commitment: a mult method scale analysis and test of effects. The International Journal of Organizational Analysis, 8(1), 89-108.

Hinkin, T. R., \& Tracey, J. B. (2000). The cost of turnover: putting a price on the learning curve. Cornell Hotel and Restaurant Administration Quarterly, 41(3), 14-21.

Hoyle, R. H. (1995). The structural equation modeling approach: basic concepts and fundamental issues. In R. H. Hoyle (Ed.), Structural equation modeling: Concepts, issues, and applications (pp. 1-15). Thousand Oaks, CA: Sage Publications, Inc.

Ineson, E. M., Benke, E., \& Laszlo, J. (2013). Employee loyalty in Hungarian hotels. International Journal of Hospitality Management, 32, 31-39.

Iverson, R. D., \& Deery, M. (1997). Turnover culture in the hospitality industry Human Resource Management Journal, 7(4), 71-82.

Jang, J., \& George, R. T. (2012). Understanding the influence of polychronicity on job satisfaction and turnover intention: a study of non-supervisory hotel employees. International Journal of Hospitality Management, 31(2), 588-595.

Johnson, S., Cooper, C., Cartwright, S., Donald, I., Taylor, P., \& Millet, C. (2005). The experience of work-related stress occupations. Journal of Management Psychology, 20(2), 178-187.

Joo, B. K., \& Park, S. (2009). Career satisfaction, organizational commitment and turnover intention. Leadership and Organizational Development Journal, 31(6) $482-500$.

Judge, T. A., \& Kammeyer-Mueller, J. D. (2012). Job attitudes. Annual Review of Psychology, 63, 341-367.

Kanungo, R. (1979). The concept of alienation and involvement revisited. Psychological Bulletin, 86, 119-138.

Kanungo, R. (1982). Measurement of job and work involvement. Journal of Applied Psychology, 67(3), 341-349.

Karatepe, O. M., Avci, T., Karatepe, T., \& Canozer, S. (2003). The measurement of job satisfaction: an empirical study of frontline employees in the northern Cyprus hotel industry. International Journal of Hospitality E Tourism Administration, 4(1), 69-85

Karatepe, O. M., \& Kilic, H. (2007). Relationships of supervisor support and conflicts in the work-family interface with the selected job outcomes of frontline employees. Tourism Management, 28(1), 238-252.

Karatepe, O. M., Uludag, O., Menevis, I., Hadzimehmedagic, L., \& Baddar, L. (2006). The effects of selected individual characteristics on frontline employee performance and job satisfaction. Tourism Management, 27, 547-560. 
Keegan, S. N., \& Lucas, R. (2005). Hospitality and hostility: dealing with low response rates in postal surveys. International Journal of Hospitality Management, 24(2), 157-169.

Ketchand, A. A., \& Strawser, J. R. (2001). Multiple dimensions of organizational commitment: implications for future accounting research. Behavioral Research in Accounting, 13, 221-251.

Khan, K., \& Nemati, A. L. (2011). Impact of job involvement on employee satisfaction: a study based on medical doctors working at Riphah International University Teaching Hospitals in Pakistan. African Journal of Business Management, 5(6), 2241-2246.

Knowles, T., \& Curtis, S. (1999). The market viability of European mass tourist destinations. A post-stagnation life-cycle analysis. International Journal of Tourism Research, 1, 87-96.

Konovsky, M. A., \& Cropanzano, R. (1991). Perceived fairness of employee drug testing as a predictor of employee attitudes and job performance. Journal of Applied Psychology, 76(5), 698-707.

Kosmoski, G. (1997). Supervision. Mequon, WI: Stylex Publishing Company.

Kuruüzüm, A., Cetin, E. I., \& Irmak, S. (2009). Path analysis of organizationa commitment, job involvement and job satisfaction in the Turkish hospitality industry. Tourism Review, 64(1), 4-16.

Labatmediene, L., Endriulaitiene, A., \& Gustainiene, L. (2007). Individual correlates of organizational commitment and intention to leave the organization. Baltic Journal of Management, 2(2), 196-212.

Lam, T., Zhang, H., \& Baum, T. (2001). An investigation of employees' job satisfaction: the case of hotels in Hong Kong. Tourism Management, 22(2), 157-165.

Lambert, E. G., Hogan, N. L., \& Barton, S. M. (2001). The impact of job satisfaction on turnover intent: a test of structural measurement model using a nationa sample of workers. The Social Science Journal, 38(2), 233-250.

Lambert, E. G., Lewig, K. A., \& Dollard, M. F. (2003). Emotional dissonance, emotional exhaustion and job satisfaction in call center workers. European Journal of Work and Organizational Psychology, 12(4), 366-392.

Lanquar, R. (2011). Tourism in the Mediterranean: Scenarios up to 2030. Retrieved 14.10.12, from www.medpro-foresight.eu.

Lashley, C. (2001). Costing staff turnover in hospitality service organizations. Journal of Services Research, 1(2), 3-24.

Lingard, H. (2003). The impact of individual and job characteristics on burnout among civil engineers in Australia and the implications for employee turnover. Construction Management and Economics, 21(1), 69-80.

Mathieu, J., \& Zajac, D. (1990). A review and meta-analysis of the antecedents correlates and consequences of organizational commitment. Psychological Bulletin, 108, 171-194.

Meyer, J. P., \& Allen, N. J. (1991). A three-component conceptualization of organizational commitment. Human Resource Management Review, 1, 61-89.

Meyer, J. P., Stanley, D. J., Herscovitch, L., \& Topolnytsky, L. (2002). Affective, continuance, and normative commitment to the organization: a meta-analysis of antecedents, correlates, and consequences. Journal of Vocational Behavior, 61 $20-52$.

Morrow, P. (1983). Concept redundancy in organizational research: the case of work commitment. Academy of Management Review, 8, 486-500.

Mulaik, S. A., James, L. R., Van Alstine, J., Bennett, N., Lind, S., \& Stilwell, C. D. (1989) Evaluation of goodness-of-fit indices for structural equation models. Psychological Bulletin, 105, 430-445.

Nadiri, H., \& Tanova, C. (2010). An investigation of the role of justice in turn over intentions, job satisfaction, and organizational citizenship behavior in hospitality industry. International Journal of Hospitality Management, 29(1) $33-41$.

Namasivayam, K., \& Zhao, X. (2007). An investigation of the moderating effects of organizational commitment on the relationships between work-family conflict and job satisfaction among hospitality employees in India. Tourism Management, 28(5), 1212-1223.

Nunnally, J. C., \& Bernstein, I. H. (1994). Psychometric theory (3rd ed.). New York, NY: McGraw-Hill.

Ogbeide, G. C. A., \& Harrington, R. J. (2011). The relationship among participative management style, strategy implementation success, and financial performance in the foodservice industry. International Journal of Contemporary Hospitality Management, 23(6), 719-738.

O'Leary, S., \& Deegan, J. (2005). Career progression of Irish tourism and hospitality management graduates. International Journal of Contemporary Hospitality Management, 17(5), 421-432.

O'Reilly, C. A., Chatman, J. A., \& Caldwell, D. F. (1991). People and organizationa culture: a profile comparison approach to assessing person-organization fit Academy of Management Journal, 34(3), 487-516.

Palmer, T., \& Riera, A. (2003). Tourism and environmental taxes. With special reference to the Balearic ecotax. Tourism Management, 24(6), 665-674.

Paullay, I., Alliger, G., \& Stone-Romero, E. (1994). Construct validation of two instruments designed to measure job involvement and work centrality. Journal of Applied Psychology, 79(2), 224-228.

Pfeffer, J. (1994). Competitive advantage through people: Unleashing the power of the work force. Boston, MA: Harvard Business School Press.

Pfeffer, J. (May-June 1998). Six dangerous myths about pay. Harvard Business Review, 110-119.

Poe, A. C. (February 2003). Keeping hotel employees: it takes more than money to retain lower-paid employees. HR Magazine, 91-92.

Psyllides, G. (25 October 2012). Minister suggests moratorium on work permits for third-country nationals. Cyprus Mail (Newspaper).
Robbins, S., \& Judge, T. A. (2007). Organizational behavior (12th ed.). Upper Saddle River, New Jersey: Prentice-Hall.

Rotenberry, P. F., \& Moberg, P. J. (2007). Assessing the impact of job involvement on performance. Management Research News, 30(3), 203-215.

Ryan, C., Ghazali, H., \& Mohsin, A. (2011). Determinants of intention to leave a nonmanagerial job in the fast-food industry of West Malaysia. International Journal of Contemporary Hospitality Management, 23(3), 344-360.

Shakeela, A., \& Cooper, C. (2009). Human resource issues in a small island setting: the case of the Maldivian tourism industry. Tourism Recreation Research, 34(1), $67-79$.

Sharpley, R., \& Forster, G. (2003). The implications of hotel employee attitudes for the development of quality tourism: the case of Cyprus. Tourism Management, 24(6), 687-697.

Simons, T., \& Hinkin, T. (2001). The effect of employee turnover on hotel profits: a test across multiple hotels. Cornell Hotel and Restaurant Administration Quarterly, 42(4), 65-69.

Stallworth, H. L. (2004). Antecedents and consequences of organizational commitment to accounting organizations. Managerial Auditing Journal, 19(7), 945-955.

Statistical Service of the Republic of Cyprus. Tourism statistics 1999-2011. Retrieved 14.10.12, from http://www.mof.gov.cy/mof/cystat/statistics.nsf/All/BBBC6C86EC D6CE66C2257762003D0654/\$file/TOURISM_STATISTICS-A99_11-EN-140512. xls?OpenElement.

Statistical Service of the Republic of Cyprus. Labor statistics 2009. Retrieved 14.10.12, from http://www.mof.gov.cy/mof/cystat/statistics.nsf/All/45093BCB88A1C158C 2257712003F5524/\$file/LABOUR_STATISTICS-2009.pdf?OpenElement.

Steel, R. P., \& Ovalie, N. K. (1984). A review and meta-analysis of research on the relationship between behavioral intentions and employee turnover. Journal of Applied Psychology, 69(4), 673-686.

Steiger, J. H. (2007). Understanding the limitations of global fit assessment in structural equation modeling. Personality and Individual Differences, 42(5), 893-898.

Tabachnick, B. G., \& Fidell, L. S. (2007). Using multivariate statistics (5th ed.). New York: Allyn and Bacon.

Tayyeb, S., \& Riaz, N. (2004). Validation of the three-component model of organizational commitment in Pakistan. Pakistan Journal of Psychological Research, 19(3/4), 123-149.

Testa, M. R. (2001). Organizational commitment, job satisfaction, and effort in the service environment. The Journal of Psychology, 135(2), 226-236.

Theocharous, A., \& Philaretou, A. G. (2009). Sexual harassment in the hospitality industry in the Republic of Cyprus: theory and prevention. Journal of Teaching in Travel E' Tourism, 9(3-4), 288-304.

Thompson, B. (2000). Ten commandments of structural equation modeling. In L. G. Grimm, \& P. R. Yarnold (Eds.), Reading and understating of multivariate statistics (pp. 261-283). Washington, DC: American Psychological Association.

Weiss, D. J., Dawis, R. V., England, G. W., \& Lofquist, L. H. (1967). Manual for the Minnesota satisfaction questionnaire. In Minnesota studies on vocational rehabilitation (Vol. 22). Minneapolis, Minnesota: University of Minnesota Industrial Relations Center:

Yang, J. T. (2010). Antecedents and consequences of job satisfaction in the hotel industry. International Journal of Hospitality Management, 29(4), 609-619.

Yang, J. T., Wan, C. H., \& Fu, Y. J. (2012). Qualitative examination of employee turnover and retention strategies in international tourist hotels in Taiwan. International Journal of Hospitality Management, 31(3), 837-848.

Yeh, C. M. (2013). Tourism involvement, work engagement and job satisfaction among frontline hotel employees. Annals of Tourism Research, 42, 214-239.

Yin-Fah, B. C., Foon, Y. S., Chee-Leong, L., \& Osman, S. (2010). An exploratory study on turnover intention among private sector employees. International Journal of Business and Management, 5(8), 57-64.

Yousef, D. A. (2000). Organizational commitment: a mediator of the relationships of leadership behavior with job satisfaction and performance in a nonwestern country. Journal of Managerial Psychology, 15(1), 6-16.

Zeithaml, V. A., \& Bitner, M. J. (2000). Service marketing: Integrating customer focus across the firm. Boston, MA: Irwin McGraw-Hill.

Zopiatis, A., \& Constanti, P. (2007). Human resource challenges confronting the Cyprus hospitality industry. EuroMed Journal of Business, 2(2), 135-153.

Zopiatis, A., \& Constanti, P. (2010). Leadership styles and burnout: is there an association? International Journal of Contemporary Hospitality Management, 22(3), $300-320$

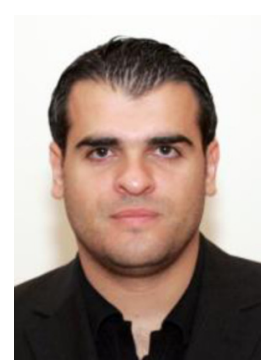

Anastasios Zopiatis, a Hotel and Tourism Management Assistant Professor at the Cyprus University of Technology, holds a BSc from the University of Southern Illinois at Carbondale, an MSc from the University of Nevada at Las Vegas, and a Doctorate in Professional Studies from Middlesex University (UK). In the past he worked in private tertiary education in Cyprus, both as a hospitality and tourism educator and program coordinator. He has also worked in Las Vegas as a Human Resources Specialist and Beverage Manager. His research interests include hospitality internships, human resources management issues, and ethics in the academic environment. His work has been published in leading journals such as the International Journal of Hospitality Management, and the Journal of Business Ethics. 


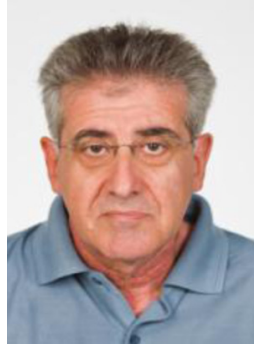

Panayiotis Constanti Prior to embarking on a career in academia, Panayiotis had more than twenty years of business experience, having held managerial posts in the local hotel industry. This has also informed his teaching in the people management/organizational behavior and business ethics fields, while his main research interests, also informed by his involvement at the 'sharp end' of the business world, focus on the various dimensions of why people work. He has also investigated aspects of pedagogy such as best practice in learning and teaching, including the pastoral aspects of the student experience having published in a number of peer-reviewed, academic journals including the Service Industries Journal, the International Journal of Education Management, and the International Journal of Contemporary Hospitality Management.

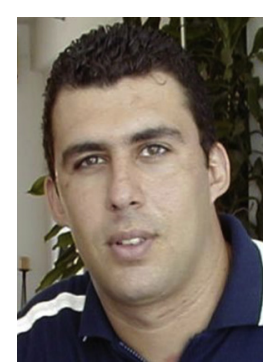

Antonis L. Theocharous is an Assistant Professor in the Department of Hotel and Tourism Management at the Cyprus University of Technology. He received his Ph.D. in Business Administration from the University of Sunderland. As part of his research activity he has secured international recognition and over 4 million Euro in research funds. He is the national representative of the Program for Social Sciences and Humanities of EU's 7th Framework Program. He has also served as national coordinator for two ESFRI projects: the European Social Survey and the Digital Research Infrastructure for the Arts and Humanities. He has published in leading peer-reviewed journals, with his major focus on political instability as it relates to tourism development, cross-cultural impacts, and mass media depictions. 